\title{
Structural Studies of $\alpha$-Crystallin
}

\author{
BY S. G. WALEY \\ Nuffield Laboratory of Ophthalmology, University of Oxford
}

(Received 4 February 1965)

\begin{abstract}
1. $\alpha$-Crystallin has been isolated from the cortex of ox lens by isoelectric precipitation followed by chromatography on DEAE-cellulose. The amino acid composition is in agreement with that reported for $\alpha$-crystallin prepared by a different method. There is one thiol group $/ 20000 \mathrm{~g}$. of protein $(20000$ is the order of magnitude of the sub-unit molecular weight), and disulphide bonds are absent. 2. The thiol group has been alkylated with radioactive iodoacetate in the presence of urea. 3. Partial acid hydrolysis of the alkylated protein gives, according to the conditions, mainly three radioactive peptides or nearly exclusively one radioactive dipeptide. The dipeptide is $N$-seryl-( $S$-carboxymethyl)cysteine, Ser-CMCys. The two other peptides are probably the tripeptides related to Ser-CMCys. 4. The simplest interpretation of these results is that the sequence around the cysteine residue is a common structural feature of the sub-units of $\alpha$-crystallin.
\end{abstract}

About one-third of the weight of lens is due to the proteins that it contains, and the nature and state of these proteins must be important in maintaining the clarity of the lens. The best known of the lens proteins is $\alpha$-crystallin, the main constituent of the fraction precipitated at $\mathrm{pH} 5$. This was the original (Mörner, 1894) characteristic property defining $\alpha$-crystallin, but, since Hesselvik (1939) identified $\alpha$-crystallin as the component migrating most rapidly towards the anode on electrophoresis, several preparative methods have utilized this property (Bloemendal \& Ten Cate, 1959; Björk, 1960; Wood \& Burgess, 1961; Manski, Halbert \& Auerbach, 1961). Isoelectric (pH5) precipitation, however, continues to be employed (François, Rabaey \& Wieme, 1955; Hähnel, 1961 ; Thomann, 1962 ; Niyogi \& Koenig, 1963) and since it is easily carried out on a large scale this was the first step used in the present work. Further purification of $\alpha$-crystallin is nowadays usually effected by chromatography (Manski et al. 1961 ; Papaconstantinou, Resnik \& Saito, 1962 ; Björk, 1963; Spector, 1964).

The $\alpha$-crystallin obtained by these methods from bovine lens appears to be a moderately wellcharacterized but labile entity. The protein has a high 'preparative molecular weight' (Reithel, 1963 ) of about 800000 , and ready dissociation and aggregation make it difficult to interpret physicochemical criteria of homogeneity. Thus Björk (1963) isolated two components that differed in their electrophoretic mobilities but had the same amino acid composition and immunochemical properties; the relative amounts of the two varied with age, and lenses from animals more than 1 year old contained only one of the components. The high preparative molecular weight and lability suggest the presence of sub-units, and Bloemendal, Bont, Jongkind \& Wisse (1962) found that the apparent molecular weight of $\alpha$-crystallin in $7 \mathrm{M}$-urea was only 26000 . Removal of the urea permitted the sub-units to associate (Bloemendal et al. 1962), so that the dissociation into sub-units is reversible. This finding immediately raises several questions, e.g. are the sub-units composed of single peptide chains? How are the sub-units structurally related? The work described in the present paper is a beginning towards answering these structural questions.

There is little published work that bears on these questions, but Bloemendal \& Ten Cate (1959) reported that the $N$-terminal residue of $\alpha$-crystallin was glutamic acid. The amount obtained corresponded to one residue $/ 78000 \mathrm{~g}$. of protein; since recoveries tend to be low most or all of the sub-units have $N$-terminal glutamic acid or glutamine. The method used does not differentiate between these two; if glutamine is the $N$-terminal residue, cyclization to a 5-oxopyrrolidine may occur, giving a transformation product with the same apparent amino acid composition but with a different charge.

One way of studying the sub-units is to concentrate on the least abundant amino acid and this is obviously easier if the amino acid has a reactive side chain. $\alpha$-Crystallin is known to have a low content of thiol groups, and so the present approach has been to alkylate these with iodo $\left[2 .{ }^{14} \mathrm{C}\right]$ acetate and examine the number and nature of the radioactive oligopeptides formed on partial hydrolysis. The methods used here largely stem from studies of the active 
centres of enzymes (Naughton, Sanger, Hartley \& Shaw, 1960; Milstein \& Sanger, 1961). Their usefulness lies in the fact that it is relatively easy to separate the radioactive peptides from each other and hence to assess the complexity of the mixture (containing most of the possible di- and tri-peptides) formed in the later states of hydrolysis. The number of distinguishable sequences containing cysteine may then be inferred, and hence a lower limit to the number of kinds of chain present. This lower limit turned out to be unity, i.e. all the chains could be of the same kind. Since the aim was to see whether a large or small number of kinds of chain were present, little detailed study of the peptides was undertaken. It was possible to account for all of the cysteine as the sequence Ser-Cys, but since the separation of the radioactive peptides from the large number of other peptides present was clearly going to be very difficult (as noted by Milstein \& Sanger, 1961), this was not attempted.

\section{METHODS}

Column chromatography. DEAE-Cellulose (Serva Ltd., Heidelberg, Germany) was washed with $\mathrm{N}-\mathrm{NaOH}$, then $\mathrm{N}-\mathrm{HCl}$ (Peterson \& Sober, 1962), reconverted into the free base form with $\mathrm{N}-\mathrm{NaOH}$, and equilibrated with $5 \mathrm{~mm}$ phosphate buffer, $\mathrm{pH}$. The columns $(17 \mathrm{~cm}$. long $\times 4 \mathrm{~cm}$. diam.) were packed under pressure, and washed overnight in the cold room before use.

Paper chromatography. The solvents used were butan-1. ol-acetic acid-water $(40: 9: 20$, by vol.) (Waley, 1956) and butan-1-ol-acetic acid-water-pyridine (15:3:12:10, by vol.) (Waley \& Watson, 1953).

Paper electrophoresis. This was carried out at $10 \mathrm{v} / \mathrm{cm}$. in a ridge-pole apparatus, or at $80 \mathrm{v} / \mathrm{cm}$. on $75 \mathrm{~cm}$.-long strips of Whatman no. 3MM paper in a Locarte high-voltage apparatus. The buffers used were pyridine-acetate, pH4 (Grassmann, Hannig \& Plöckl, 1955), and collidine-acetate, pH 7 (Newton \& Abraham, 1954).

Separation of amino acids. This was carried out by paper electrophoresis in formic acid-acetic acid-water $(125 \mathrm{ml}$. of $90 \%, \mathrm{w} / \mathrm{v}$, formic acid and $375 \mathrm{ml}$. of acetic acid in 2.51.) followed by chromatography in the butanol-acetic acid solvent (Waley, 1964).

Detection and measurement of radioactivity. This was carried out as described by Waley (1964); sufficient counts were recorded for the standard error to be less than $5 \%$. Radioautography was carried out with Kodak Royal Blue X-ray films for 3-10 days.

1-Dimethylaminonaphthalene-5-sulphonyl derivatives. The DNS-amino acids* used as markers were prepared as described by Boulton \& Bush (1964). The formation of the DNS-peptide was carried out as described by Gray \& Hartley (1963), or by a modification in which $20 \mathrm{~m} \mu$ moles of the peptide in $10 \mu \mathrm{l}$. of water were treated with $10 \mu \mathrm{l}$. of $0.3 \mathrm{M}-\mathrm{NaHCO}_{3}$ and the mixture evaporated to remove traces of $\mathrm{NH}_{3}$, redissolved in $10 \mu \mathrm{l}$. of water and treated with

* Abbreviation: DNS-, 1-dimethylamino-naphthalene-5sulphonyl-.
$10 \mu \mathrm{l}$. of acetone containing $125 \mu \mathrm{g}$. of 1-dimethylaminonaphthalene-5-sulphonyl chloride. After $2 \mathrm{hr}$. the mixture was evaporated and hydrolysed (Gray \& Hartley, 1963). Certain DNS-amino acids have been found to be most easily identified by thin-layer chromatography.

Thin-layer chromatography. This was carried out on $0.25 \mathrm{~mm}$. layers of silica gel $\mathrm{G}$ dried at room temperature. The solvent was $3 \mathrm{ml}$. of buffer $(14 \mathrm{ml}$. of triethylamine was acidified to $\mathrm{pH} 3$ with acetic acid and the mixture diluted to $100 \mathrm{ml}$.) and $120 \mathrm{ml}$. of ethyl acetate. In this solvent, 1-dimethylaminonaphthalene-5-sulphonic acid stays at the origin, and 1-dimethylaminonaphthalene-5-sulphonamide travels ahead of the DNS-amino acids. DNS-S-carboxymethylcysteine and DNS-serine travel behind the other DNS-amino acids, and are separated; DNS-serine is the faster of the two. The DNS derivatives of the more nonpolar amino acids are not separated in this system.

\section{RESULTS}

Isolation of crude $\alpha$-crystallin. The capsules were removed from 40 ox lenses (weight $84 \mathrm{~g}$.) and the lenses stirred gently with $320 \mathrm{ml}$. of water at $4^{\circ}$ for $45 \mathrm{~min}$. to extract material from the cortex of the lens. The insoluble protein in the extract (albuminoid) was removed by centrifuging for $25 \mathrm{~min}$. at $10000 \mathrm{~g}$ at $2^{\circ}$, and the supernatant brought to $\mathrm{pH} 5$ with $10 \%(\mathrm{v} / \mathrm{v})$ acetic acid at $4^{\circ}$ and kept overnight at $4^{\circ}$. The precipitate, collected by centrifuging (under the conditions described above), was stirred with $50 \mathrm{ml}$. of water at $4^{\circ}$ and brought into solution by the addition of $10 \%(\mathrm{v} / \mathrm{v})$ acetic acid to lower the $\mathrm{pH}$ to 4. A small amount of undissolved material was removed by centrifuging and the solution brought to $\mathrm{pH} 5$ by the addition of $0.2 \mathrm{M}$-sodium hydrogen carbonate. The precipitate of crude $\alpha$-crystallin was collecting by centrifuging and dissolved by stirring with $50 \mathrm{ml}$. of water and raising the $\mathrm{pH}$ to 7 by the addition of aqueous disodium hydrogen phosphate. The solution was then dialysed for $48 \mathrm{hr}$. against $5 \mathrm{~mm}$-phosphate buffer, $\mathrm{pH} 7$, and clarified by centrifuging. The yield of $\alpha$-crystallin was about $1.5 \mathrm{~g}$., from the $E_{280}$ value.

Purification of $\alpha$-crystallin by chromatography. A portion ( $31 \mathrm{ml}$. containing about $900 \mathrm{mg}$. of protein) of the above solution was diluted to $100 \mathrm{ml}$. with 5 mM-phosphate buffer, pH 5.8, and applied to the DEAE-cellulose column. The column was eluted with $600 \mathrm{ml}$. of $20 \mathrm{~mm}$-phosphate buffer, $\mathrm{pH} \mathrm{5.8,} \mathrm{and}$ then with a linear gradient: the mixer contained $700 \mathrm{ml}$. of $20 \mathrm{~mm}$-phosphate buffer, pH 5.8, and the reservoir contained $700 \mathrm{ml}$. of a solution $0.14 \mathrm{M}$ with respect to sodium dihydrogen phosphate and $0.3 \mathrm{M}$ with respect to sodium chloride. The $\alpha$-crystallin (about 240mg.) was eluted in fractions 62-87, 1309-1806 ml. (Fig. 1), and was precipitated by the addition of $120 \mathrm{~g}$. of ammonium sulphate. The precipitate was dissolved in $5 \mathrm{~mm}$-ammonium hydrogen carbonate, desalted on Sephadex G-25 and recovered by freeze-drying. 


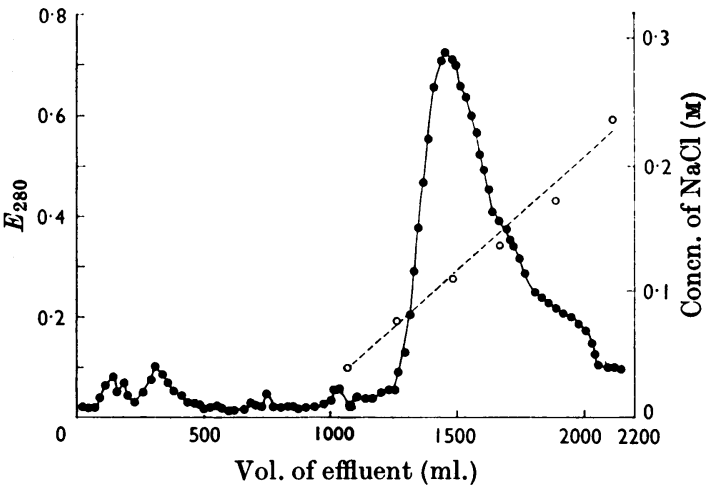

Fig. 1. Chromatography of crude $\alpha$-crystallin on DEAEcellulose. About $900 \mathrm{mg}$. of protein was applied to the column, and eluted first with $600 \mathrm{ml}$. of $20 \mathrm{~mm}$-phosphate buffer, pH5.8, and then with a linear gradient: the mixer contained this buffer and the reservoir contained a solution $0 \cdot 14 \mathrm{M}$ with respect to $\mathrm{NaH}_{2} \mathrm{PO}_{4}$ and $0.3 \mathrm{M}$ with respect to $\mathrm{NaCl}$. The solid line gives $\boldsymbol{E}_{280}$ and the broken line indicates the gradient, from the measured values of the concentration of $\mathrm{Cl}^{-}$ion.

\section{Table 1. Amino acid analyses of $\alpha$-crystallin}

Experimental details are given in the text, as is the basis for the calculation of the integral number of residues. The integral number of residues in the last column is an average value from Björk (1963), assuming that there are six residues of alanine.

\begin{tabular}{|c|c|c|c|}
\hline \multirow[b]{2}{*}{ Amino acid } & \multirow{2}{*}{$\begin{array}{c}\text { Analysis } \\
\text { ( } \mu \text { moles } \\
\text { found) }\end{array}$} & \multicolumn{2}{|c|}{ No. of residues } \\
\hline & & Present work & Björk (1963) \\
\hline Lys & 0.994 & 8 & 7 \\
\hline His & 0.961 & 8 & 6 \\
\hline Arg & $1 \cdot 546$ & 12 & 12 \\
\hline Cys & $0 \cdot 133^{*}$ & 1 & $(1) \ddagger$ \\
\hline Asp & $1 \cdot 739$ & 14 & $15^{+1+}$ \\
\hline Thr & 0.649 & 5 & 5 \\
\hline Ser & 1.972 & $17 \dagger$ & $17 \dagger$ \\
\hline Glu & $1 \cdot 981$ & 16 & 17 \\
\hline Pro & $1 \cdot 420$ & 11 & 11 \\
\hline Gly & $1 \cdot 229$ & 10 & 7 \\
\hline Ala & $0 \cdot 777$ & 6 & 6 \\
\hline Val & $1 \cdot 092$ & 9 & 10 \\
\hline Met & 0.232 & 2 & 2 \\
\hline Ile & 0.888 & 7 & 8 \\
\hline Leu & $1 \cdot 549$ & 12 & 13 \\
\hline Tyr & 0.612 & 5 & 5 \\
\hline Phe & $1 \cdot 508$ & 12 & 13 \\
\hline & & $\overline{155}$ & $\overline{155}$ \\
\hline
\end{tabular}

* Determined as cysteic acid after hydrolysis of oxidized protein.

† Corrected assuming $10 \%$ loss on hydrolysis.

$\uparrow$ Calculated from the reported $S$ content, allowing for methionine.
Amino acid analysis of $\alpha$-crystallin. Hydrolysis with redistilled $6 \mathrm{~N}$-hydrochloric acid in a sealed evacuated tube at $110^{\circ}$ for $16 \mathrm{hr}$. was carried out as described by Moore \& Stein (1963). I am very grateful to Dr D. B. Hope, who carried out the amino acid analysis. The results are given in Table 1 as $\mu$ moles of amino acid found, and as assumed numbers of residues (column 3). The values in column 3 were obtained as follows. The total number of $\mu$ moles found was corrected to a value of 19.5 by assuming $10 \%$ loss of serine and $5 \%$ loss of threonine and tyrosine (Moore \& Stein, 1963), and by assuming that there were two residues of tryptophan (see below) to five residues of tyrosine. The amino acids present in lowest amounts were cysteine and methionine, and it was further assumed that there was one residue of cysteine and two residues of methionine. The radioactivity of the protein after treatment with iodo[2.14C]acetate (see below) was also consistent with the presence of one residue of cysteine. The proportion of methionine obtained after hydrolysis of the unoxidized protein was similar to the proportion of methionine sulphone obtained after hydrolysis of the protein oxidized as described by Moore (1963), assuming that the amounts of aspartic acid in both hydrolysates were the same. The values of $0.232 \mu$ mole of methionine, and of $0.251 \mu$ mole of methionine sulphone and $0.133 \mu$ mole of cysteic acid (in the hydrolysate of oxidized protein) in a total of $19.5 \mu$ moles, gives values for the total number of amino acid residues as 168,155 and 147 . The mean value (157) was then used to estimate the numbers of residues in column 3. For comparison, the values obtained by Björk (1963) have been recalculated assuming the presence of six residues of alanine and are given in column 4 (to the nearest integer).

The absorption spectrum of $\alpha$-crystallin in $0 \cdot 1 \mathrm{~N}$-sodium hydroxide, analysed by the method of Bencze \& Schmid (1957), gave a tyrosine/tryptophan ratio about $2 \cdot 3$. On the basis of five residues of tyrosine (Table 1), there are then two residues of tryptophan.

Reaction of $\alpha$-crystallin with sodium iodo[2-14C]acetate. $\alpha$-Crystallin ( $17 \mathrm{mg}$.) in $1 \mathrm{ml}$. of $0.1 \mathrm{~m}$-sodium hydrogen carbonate was added to $0.6 \mathrm{ml}$. of aqueous sodium iodo[2-14 $\mathrm{C}]$ acetate $(12.4 \mu$ moles containing $2 \mu \mathrm{C}$; equivalent to 3700 counts/sec. under the conditions used for counting). The solutions were mixed, and then $0.825 \mathrm{~g}$. of urea was added (the urea had been purified by the method of Benesch, Lardy \& Benesch, 1955). After being kept for $30 \mathrm{~min}$. at room temperature, the reaction mixture was diluted to $4 \mathrm{ml}$. with $5 \mathrm{~mm}$-ammonium hydrogen carbonate, and then submitted to gel filtration on a column $(2.7 \mathrm{~cm} . \times 14 \mathrm{~cm}$. long) of Sephadex G-25 with the same buffer. Excess of radioactive reagent was well separated from the 
protein, and the samples of protein in fractions 4-7 had nearly the same specific activity (Fig. 2). From the value of the specific extinction coefficient given by Björk (1963) the mean value for the weight of protein containing 1 mole of an alkylated group is 23200 g.

The reaction was also carried out with about $100 \mathrm{mg}$. of $\alpha$-crystallin and $38 \mu$ moles of iodo[2-14 $\mathrm{C}$ acetate containing $4 \times 10^{4}$ counts $/ \mathrm{sec}$. The protein, recovered (after gel filtration) by freeze-drying, had specific activity about 43 counts/sec./mg. of protein; this value corresponds to the extent of alkylation recorded above.

Little or no radioactivity was incorporated into the protein in the absence of urea.

Complete acid hydrolysis of carboxymethyl- $\alpha$ crystallin. A sample (1.35 mg.) of the alkylated protein was hydrolysed with redistilled $6 \mathrm{~N}$-hydrochloric acid in an evacuated sealed tube for $16 \mathrm{hr}$. at $115^{\circ}$. The hydrolysate was examined by paper electrophoresis at $\mathrm{pH} 4$; the only radioactive spot (detected by radioautography) coincided exactly with the position occupied by $S$-carboxymethylcysteine.

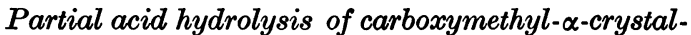
lin. Expt. 1: hydrolysis in aqueous hydrochloric acid. Carboxymethyl- $\alpha$-crystallin (45.6 mg.) was heated with $6 \mathrm{~N}$-hydrochloric acid $(2 \mathrm{ml}$.$) in a sealed$ evacuated tube for $48 \mathrm{hr}$. at $37^{\circ}$; most, but not all, of the protein dissolved gradually. The precipitate was removed by centrifuging, and the supernatant
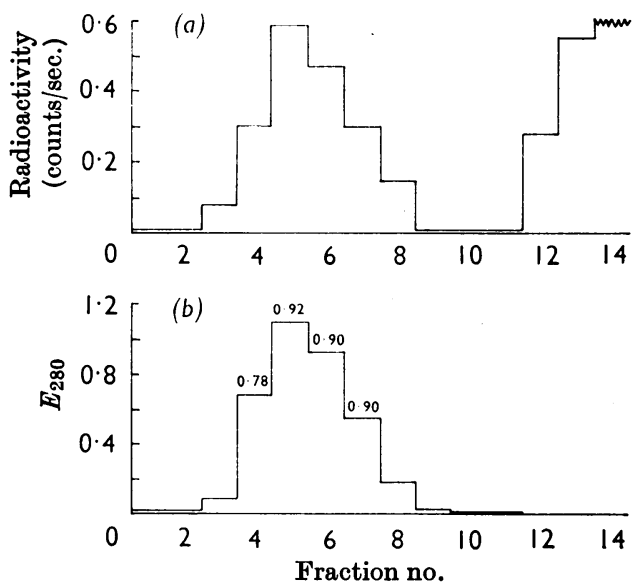

Fig. 2. Chromatography on Sephadex G-25 of reaction mixture from $\alpha$-crystallin and iodo[2-14C]acetate. The reaction mixture (for details see the text) was applied to a column $(2.7 \mathrm{~cm} . \times 14 \mathrm{~cm}$. long) and eluted with $5 \mathrm{~mm}$ $\mathrm{NH}_{4} \mathrm{HCO}_{3}$. After $19 \mathrm{ml}$. had passed through the column, $3 \mathrm{ml}$. fractions were collected: $E_{280}$ was measured (b) and $0.05 \mathrm{ml}$. portions were taken and counted $(a)$. The values above the bars give moles of ${ }^{14} \mathrm{C}$ bound/20000 g. of protein. was evaporated, and hydrogen chloride removed by adding water and evaporating three times. The residue, in $0.2 \mathrm{ml}$. of $\mathrm{pH} 4$ buffer, was spread over an $18 \mathrm{~cm}$. band on Whatman no. 3 paper and fractionated by electrophoresis (Fig. 3). Bands $A, B$ and $C$ were eluted, and the main band $(A)$ was further fractionated by electrophoresis at $\mathrm{pH} 7$; the starting line was $20 \mathrm{~cm}$. from the cathode on a $57 \mathrm{~cm}$.-long sheet of Whatman no. 3 paper, and electrophoresis was carried out for $6 \mathrm{hr}$. at $500 \mathrm{v}$. Radioautography showed only one band, which was eluted, and portions of the eluate were used for determination of the amino acid composition and $N$-terminal amino acid.

Comparable amounts of $S$-carboxymethylcysteine and of serine were present in the hydrolysate; serine was identified as the $N$-terminal amino acid by the 'DNS' procedure (see the Methods section). These results suggested that peptide $A$ was SerCMCys [ $N$-seryl-( $S$-carboxymethyl)cysteine].

The interrelationship of bands $A, B$ and $C$ was investigated. Further partial acid hydrolysis of

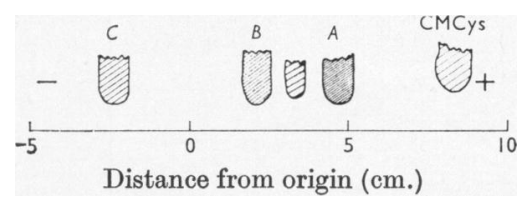

Fig. 3. Electrophoresis at $\mathrm{pH} 4$ for $4 \mathrm{hr}$. at $10 \mathrm{v} / \mathrm{cm}$. of products from hydrolysis of carboxymethyl- $\alpha$-crystallin in $6 \mathrm{~N}-\mathrm{HCl}$ at $37^{\circ}$ for $48 \mathrm{hr}$. The depth of hatching indicates the extent of blackening of the $\mathrm{X}$-ray film after radioautography. The scale shows the distance travelled: zero is the position occupied by neutral amino acids, and travel towards the anode is taken as positive.

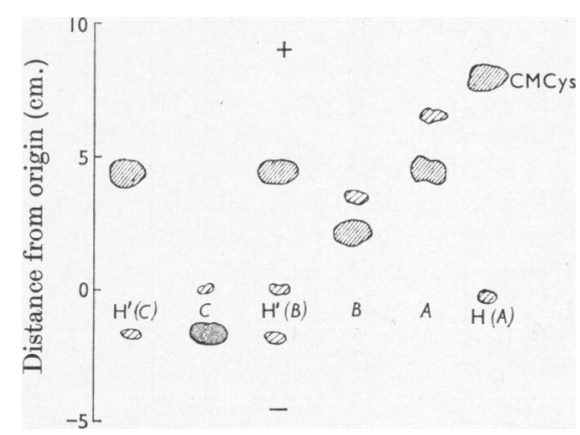

Fig. 4. Electrophoresis and radioautography of hydrolysates of radioactive peptides. The conditions of electrophoresis were as given in Fig. 3. Spots $A, B$ and $C$ are samples of the eluates from the experiment of Fig. 3. $\mathrm{H}^{\prime}(B)$ and $\mathrm{H}^{\prime}(C)$ indicate partial hydrolyses of $B$ and $C$ respectively; hydrolysis was for $7 \mathrm{~min}$. at $100^{\circ}$ in acetic acid-conc. $\mathrm{HCl}(1: 1, \mathrm{v} / \mathrm{v}) . \mathrm{H}(A)$ is the total acid hydrolysate of $A$. 
bands $B$ and $C$ was carried out in acetic acidconcentrated hydrochloric acid $(1: 1, \mathrm{v} / \mathrm{v})$ at $100^{\circ}$ for $7 \mathrm{~min}$. The main radioactive product, in both cases, had the electrophoretic mobility of band $A$ (Fig. 4), and also gave a spot of the same $R_{F}$ as band $A$ on paper chromatography in butanol-acetic acidwater-pyridine. This suggested that bands $B$ and $C$ were the tripeptides related to $A$, i.e. X-SerCMCys and Ser-CMCys-Y, where $X$ and $Y$ stand for (unidentified) amino acids. The electrophoretic mobilities of bands $B$ and $C$ suggest that one of the pair $\mathrm{X}$ and $\mathrm{Y}$ is a neutral amino acid (in $B$ ) and one a basic amino acid (in $C$ ). There was no evidence for the formation of the (radioactive) dipeptide CMCys-Y, and only traces of free CMCys were formed.

Expt. 2: Hydrolysis in acetic acid-hydrochloric acid. As the protein was only partially soluble in aqueous hydrochloric acid, acetic acid was used in further experiments. Carboxymethyl- $\alpha$-crystallin (33 mg.) in acetic acid ( $1 \mathrm{ml}$.) and concentrated hydrochloric acid ( $1 \mathrm{ml}$.) were heated at $37^{\circ}$ for 42hr. in a sealed evacuated tube. The purple solution was evaporated and the mixture fractionated as in Expt. 1. The hydrolysis was more selective than in Expt. 1, and band $A$ was virtually the only radioactive product. It was further fractionated by electrophoresis at $\mathrm{pH} 7$ for $70 \mathrm{~min}$. at $80 \mathrm{v} / \mathrm{cm}$.; the starting line was $20 \mathrm{~cm}$. from the cathode end of the $75 \mathrm{~cm}$.-long strip of Whatman no. 3MM paper. The radioactive band $A$ had travelled $22 \mathrm{~cm}$; a marker spot of glutamic acid had travelled $31 \mathrm{~cm}$.

Edman degradation was carried out as follows. A portion of the eluate of band $A$ containing about 100 counts/sec., corresponding to about $80 \mathrm{~m} \mu \mathrm{moles}$, was treated with $0.2 \mathrm{ml}$. of $50 \%(\mathrm{v} / \mathrm{v})$ pyridine and $0.1 \mathrm{ml}$. of $5 \%(\mathrm{v} / \mathrm{v})$ phenyl isothiocyanate in pyridine for $2.5 \mathrm{hr}$. at $36^{\circ}$. Water $(0.2 \mathrm{ml}$.) and benzene ( $2 \mathrm{ml}$.) were then added, and the mixture was equilibrated and centrifuged. The top layer was withdrawn, and extraction with benzene repeated twice. The aqueous layer was freed from benzene by blowing nitrogen on to the surface, and then frozen and dried overnight. The residue was treated with $0.2 \mathrm{ml}$. of trifluoroacetic acid (at room temperature) for $1 \mathrm{hr}$., and the solution then evaporated in vacuo. The residue was dissolved in $0.04 \mathrm{ml}$. of $50 \%(\mathrm{v} / \mathrm{v})$ pyridine, and $0.02 \mathrm{ml}$. was withdrawn and $0.01 \mathrm{ml}$. of $0.1 \mathrm{M}$-sodium hydrogen carbonate added, the mixture evaporated and the residue dissolved in about $15 \mu \mathrm{l}$. of water and treated with 1-dimethylaminonaphthalene-5-sulphonyl chloride. The electrophoretic mobility at $\mathrm{pH} 7$ of the fluorescent product (DNS-A1) was compared with that of the derivative of the undegraded peptide (DNS-A). Their mobilities, measured as distance travelled (in $1 \cdot 25 \mathrm{hr}$. at $80 \mathrm{v} / \mathrm{cm}$.) measured from the spot of dimethylaminonaphthalenesulphonamide, relative to the distance travelled by dimethylaminonaphthalenesulphonic acid, were: DNS- $A, 1 \cdot 40$; DNS- $A 1,1 \cdot 46$. Marker spots had the following mobilities: DNS-CMCys, 1.48; DNS-Ser, $0 \cdot 79$. A mixture of DNS- $A$ and DNS- $A 1$ gave two spots, and this confirmed that degradation had taken place. The difference between the mobilities of DNS- $A 1$ and DNS-CMCys is within the experimental error, and these results are consistent with $A$ being Ser-CMCys, and $A 1$ being CMCys. These results thus confirm the sequence for peptide $A$ arrived at from Expt. 1.

When hydrolysis of carboxymethyl- $\alpha$-crystallin was carried out in acetic acid-hydrochloric acid for only $8 \mathrm{hr}$. at $36^{\circ}$, band $A$ was still the main product, but now there was another radioactive band $B$ present as well. This was purified by electrophoresis at $\mathrm{pH}$ 4, followed by high-voltage electrophoresis at pH 7. However, the peptide was still impure: as well as carboxymethylcysteine, serine, some leucine (or isoleucine) and traces of aspartic acid were present in the hydrolysate. The leucine (or isoleucine) may be due to contaminating peptides, and the radioactive peptide $B$ may be a tripeptide containing two residues of serine.

Expt. 3: time-course of hydrolysis of carboxymethyl- $\alpha$-crystallin. The protein $15 \mathrm{mg} . / \mathrm{ml}$. in acetic acid-concentrated hydrochloric acid, 1:1, $\mathrm{v} / \mathrm{v}$ ) was heated for various times at $100^{\circ}$ (Fig. 5a)

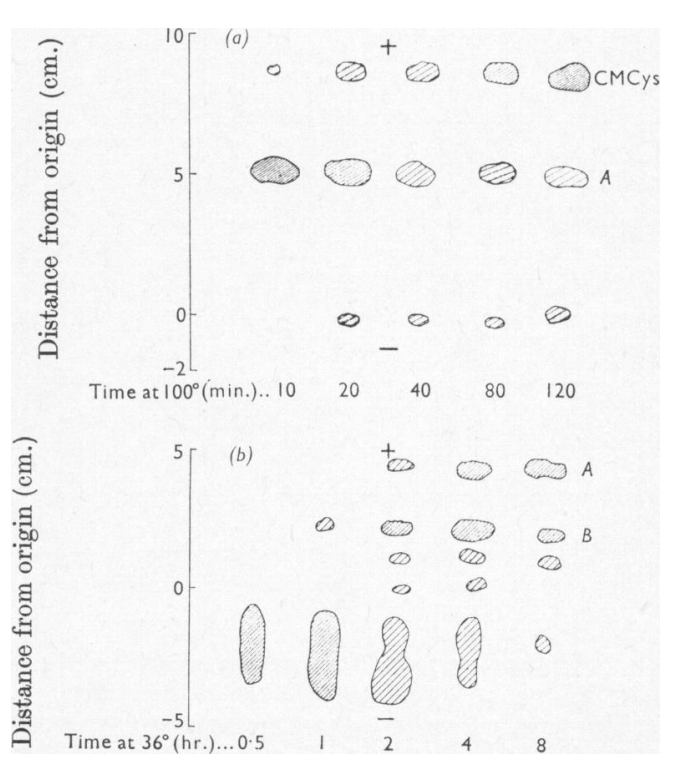

Fig. 5. Electrophoresis and radioautography showing time-course of hydrolysis of carboxymethyl- $\alpha$-crystallin. Hydrolysis at $100^{\circ}$ is shown in $(a)$ and at $36^{\circ}$ in (b). The conditions of electrophoresis were as given in Fig. 3 . 
or at $36^{\circ}$ (Fig. $5 b$ ). The samples were then freed from acid, and the products examined by electrophoresis at $\mathrm{pH} 4$ followed by radioautography. At $100^{\circ}$, the main product at early times is the dipeptide $A$, which gradually breaks down to carboxymethylcysteine. At $36^{\circ}$ after brief hydrolysis the large peptides form an unresolved streak; at later times the main products are the dipeptide $A$ and tripeptide (?) $B$.

\section{DISCUSSION}

Composition of $\alpha$-crystallin. The amino acid analysis of $\alpha$-crystallin is recorded in Table 1 . The values are also given as integral numbers of residues as a convenient basis for comparing samples of $\alpha$-crystallin. These values, which have absolute significance if the sub-units have the same composition, were calculated from the content of cysteine and methionine. There is reasonable agreement between the values obtained from the $\alpha$-crystallin described here and the average value reported by Björk (1963). Since Björk (1963) isolated the $\alpha$ crystallin by electrophoresis rather than by pH5 precipitation, the agreement between the analyses is a satisfactory confirmation that the same protein is obtained by both procedures. The results of other reported analyses of $\alpha$-crystallin (which are in general agreement) are not discussed in detail here; less reliable methods of analysis were used by Orkhovitch \& Firfarova (1959) and by Bloemendal \& Ten Cate (1959), and Hähnel (1961) used a less extensively purified sample of $\alpha$-crystallin.

The reported values for the thiol content of $\alpha$ crystallin are approximately equivalent to one residue of cysteine/20000g. [1.4 (Kinoshita \& Merola, 1958); 1.1 (Thomann, 1959); 0.6 (Spector, 1964)] and cystine is probably absent (Thomann, 1959). Both these conclusions have been confirmed in the present work. Moreover, the absence of cystine shows that the sub-units are not held together by disulphide bonds. Since the molecular weight of the sub-units (in $7 \mathrm{M}$-urea) is about 20000 (Bloemendal et al. 1962) there is (on the average) one residue of cysteine in each sub-unit. If there are several kinds of sub-unit, it would be possible for some of the sub-units to have more than one residue of cysteine while others had none, but if all the sub-units are identical then the cysteine represents a unique feature. Hence study of the peptides containing cysteine seemed worth while.

Reaction of $\alpha$-crystallin with iodoacetate. $\alpha$-Crystallin reacted with iodo[2-14C] acetate in $8 \mathrm{M}$-urea: the product is referred to as carboxymethyl- $\alpha$ crystallin. Under the conditions used, only thiol groups would be expected to react (Sela, White \& Anfinsen, 1959), and in fact after total acid hydrolysis the only radioactive product was $S$-carboxy- methylcysteine. The $\alpha$-crystallin did not react with iodoacetate unless urea had been added; unreactive thiol groups may be involved in non-polar interactions ('hydrophobic bonds') (Cecil, 1963), and it seemed possible that here the thiol group played a part in the association between the sub-units. When the urea is removed (by dialysis) from a solution of $\alpha$-crystallin in $8 \mathrm{M}$-urea, the sub-units reassociate (Bloemendal et al. 1962). Similar results were obtained when the $\alpha$-crystallin had been alkylated (with iodoacetate) in $8 \mathrm{M}$-urea; after removal of the urea, reassociation occurred. The material gave a broad peak in the ultracentrifuge, with a mean apparent sedimentation coefficient of $14 \mathrm{~s}$, and was eluted from a column of Sephadex G-200 at the same position as native $\alpha$-crystallin and earlier than serum albumin. Hence intact thiol groups are not obligatory for association of the sub-units.

Partial hydrolysis of carboxymethyl- $\alpha$-crystallin. Acid hydrolysis at $100^{\circ}$ gave a mixture that consisted almost entirely of only two radioactive components (Fig. 5a). The faster was $S$-carboxymethylcysteine and the slower was the peptide $A$. After $10 \mathrm{~min}$. peptide $A$ is virtually the sole (radioactive) product, but after reaction for longer times it is hydrolysed and carboxymethylcysteine is formed. These results suggest that $A$ is a dipeptide of carboxymethylcysteine, whose structure is such that it is formed relatively readily. Acid hydrolysis of carboxymethyl- $\alpha$-crystallin at $36^{\circ}$ did not give any free carboxymethylcysteine, but gave (after $8 \mathrm{hr}$.) mainly the peptide $A$ and another peptide $B$ (Fig. $5 b$ ). These hydrolyses were carried out in acetic acidconcentrated hydrochloric acid, and the protein readily dissolved in this medium. In aqueous $6 \mathrm{~N}$ hydrochloric acid, the protein was less soluble and degradation less rapid, and fractionation of the hydrolysate gave $A, B$ and a third peptide $C$ (Fig. 3). Peptide $A$ was identified as Ser-CMCys (where CMCys stands for $S$-carboxymethylcysteine). This structure accounts for its ready formation, as peptide bonds from serine are readily split by acid to give peptides with $N$-terminal serine (Sanger, 1952).

Further partial acid hydrolysis of peptides $B$ and $C$ gave peptide $A$ (Fig. 4). This suggests that all three peptides are derived from the sequence $X$ Ser-CMCys-Y, $B$ being Ser-CMCys-Y and $C$ being $\mathrm{X}$-Ser-CMCys (or vice versa). The electrophoretic mobility of peptide $C$ suggests that it contains a basic amino acid, whereas $B$ probably contains an unidentified neutral amino acid.

The main conclusion from these experiments is that the products could all arise from a single sequence. Other parts of the peptide chains could differ in the sub-units and the part involving cysteine could represent a common feature, but these results are consistent with all the sub-units 
having the same structure. It certainly seems unlikely that $\alpha$-crystallin contains a large number of different kinds of sub-unit.

I thank Mr R. Priscott for skilled technical assistance, the National Council to Combat Blindness Inc., New York, for grants, and the Staffs of the Oxford Co-operative Society and Eastwyck Farm Slaughterhouses for their co-operation.

\section{REFERENCES}

Bencze, W. L. \& Schmid, K. (1957). Analyt. Chem. 29, 1193. Benesch, R. E., Lardy, H. A. \& Benesch, R. (1955). J. biol. Chem. 216, 663.

Björk, I. (1960). Biochim. biophys. Acta, 45, 372.

Björk, I. (1963). Exp. Eye Res. 2, 339.

Bloemendal, H., Bont, W. S., Jongkind, J. F. \& Wisse, J. H. (1962). Exp. Eye Res. 1, 300.

Bloemendal, H. \& Ten Cate, G. (1959). Arch. Biochem. Biophys. 84, 512.

Boulton, A. A. \& Bush, I. E. (1964). Biochem. J. 92, 11 P. Cecil, R. (1963). In The Proteins, 2nd ed., vol. 1, p. 380. Ed. by Neurath, H. New York: Academic Press Inc.

François, J., Rabaey, M. \& Wieme, R. J. (1955). A. M. A. Arch. Ophthal. 53, 481.

Grassmann, W., Hannig, K. \& Plöckl, M. (1955). HoppeSeyl. Z. 299, 258.

Gray, W. R. \& Hartley, B. S. (1963). Biochem. J. 89, 59 P. Hähnel, R. (1961). v. Graefes Arch. Ophthal. 163, 283.

Hesselvik, L. (1939). Skand. Arch. Physiol. 82, 151.

Kinoshita, J. H. \& Merola, L. O. (1958). Amer. J. Ophthal. 46, 36.
Manski, W. J., Halbert, S. P. \& Auerbach, T. P. (1961). Arch. Biochem. Biophys. 92, 512.

Milstein, C. \& Sanger, F. (1961). Biochem. J. 79, 456.

Moore, S. (1963). J. biol. Chem. 238, 235.

Moore, S. \& Stein, W. H. (1963). In Methods of Enzymology, vol. 6, p. 819. Ed. by Colowick, S. P. \& Kaplan, N. O. New York: Academic Press Inc.

Mörner, C. T. (1894). Hoppe-Seyl. Z. 18, 60.

Naughton, M. A., Sanger, F., Hartley, B. S. \& Shaw, D. C. (1960). Biochem. J. 77, 149.

Newton, G. G. F. \& Abraham, E. P. (1954). Biochem. J. 58, 103.

Niyogi, S. K. \& Koenig, V. L. (1963). Biochim. biophys. Acta, 69, 283.

Papaconstantinou, J., Resnik, R. A. \& Saito, E. (1962). Biochim. biophys. Acta, 60, 205.

Peterson, E. A. \& Sober, H. A. (1962). In Methods of Enzymology, vol. 5, p. 3. Ed. by Colowick, S. P. \& Kaplan, N. O. New York: Academic Press Inc.

Orekhovitch, W. N. \& Firfarova, K. F. (1959). Bull. Soc. Chim. biol., Paris, 41, 209.

Reithel, F. J. (1963). Advanc. Protein Chem. 18, 124.

Sanger, F. (1952). Advanc. Protein Chem. 7, 1.

Sela, M., White, F. H. \& Anfinsen, C. B. (1959). Biochim. biophys. Acta, 31, 417.

Spector, A. (1964). Invest. Ophthal. 3, 182.

Thomann, H. (1959). v. Graefes Arch. Ophthal. 160, 219.

Thomann, H. (1962). v. Graefes Arch. Ophthal. 165, 219.

Waley, S. G. (1956). Biochem. J. 64, 715.

Waley, S. G. (1964). Biochem.J. 91, 576.

Waley, S. G. \& Watson, J. (1953). Biochem. J. 55, 328.

Wood, D. C. \& Burgess, L. (1961). Amer.J. Ophthal.51, 305. 